\title{
Dyeing and colour fastness of natural dye from Citrus aurantium on Lyocell fabric
}

\author{
DOI: $10.35530 / I T .071 .04 .1686$
}

NAVEED TAYYAB

RASHDI YASEEN SAYED

AWAN ASHRAF JAVEED

ABBAS MUDASSAR

FRAZ AHMAD

REHMAN FAISAL

WEI WANG

AWAIS MUHAMMAD

\section{ABSTRACT - REZUMAT}

Dyeing and colour fastness of natural dye from Citrus aurantium on Lyocell fabric

The use of natural dyes for textiles has attained attention due to their ecology, minimum impact on the environment and pollution. Therefore the objective of this study is to dye Lyocell fabric with natural dye extracted from orange peel for comparative analysis of colour efficiencies (K/S), CIE $L^{*} a^{*} b^{*}$ values and the colour fastness properties. The mordants applied were ferrous (II) sulphate and copper (II) sulphate. For the extraction of the dye, the aqueous extraction method was used. The pre-mordanting method was used and the dyeing effect on Lyocell fabric was analyzed at concentrations of $2 \%$ and $4 \%$. It was observed that the mordant type employed had an influence on the colour efficiency and the colour coordinates of fabric dyed with Citrus aurantium dye. The colour efficiency (K/S: 4) and colour fastness to washing, light, rubbing and perspiration in all the dyed samples were better and excellent (grade 4-5) at 4\% concentration. In overall results, the pre-mordanting method at $4 \%$ concentration gives the best results of colour efficiency and colour fastness properties. The performance analysis of colour fastness was also statistically significant at the 0.05 level.

Keywords: natural dyes, orange peel, Lyocell, extraction, mordant, colour fastness

\section{Vopsirea și rezistența culorii colorantului natural din Citrus aurantium pe țesătura din Lyocell}

Utilizarea coloranților naturali pentru materialele textile a atras atenția datorită aspectelor legate de ecologie, impactul minim asupra mediului și poluare. Prin urmare, obiectivul acestui studiu este vopsirea țesăturii din Lyocell cu colorant natural extras din coaja de portocală, pentru analiza comparativă a eficienței culorilor (K/S), valorile CIE $L^{*} a^{*} b^{*}$ și proprietățile de rezistență a culorii. Mordanții aplicați au fost sulfat feros (II) și sulfat de cupru (II). Pentru extragerea colorantului s-a utilizat metoda de extracție apoasă. S-a utilizat metoda cu pre-mordant și s-a analizat vopsirea pe țesătura din Lyocell la concentrații de $2 \%$ și $4 \%$. S-a observat că tipul de mordant folosit a influențat eficiența culorilor și coordonatele de culoare ale țesăturii vopsite cu colorant Citrus aurantium. Eficiența culorii (K/S: 4) și rezistența culorii la spălare, lumină, frecare și transpirație la toate probele vopsite au fost mai bune și excelente (grad 4-5) la o concentrație de $4 \%$. In ceea ce privește rezultatele generale, metoda de pre-mordansare la o concentrație de $4 \%$ oferă cele mai bune rezultate ale eficienței culorii și proprietății de rezistență a culorii. Analiza performanței rezistenței culorii a fost, de asemenea, semnificativă statistic la nivelul 0,05.

Cuinte-cheie: coloranți naturali, coajă de portocală, Lyocell, extracție, mordant, rezistența culorii

\section{INTRODUCTION}

Since 1856, the use of synthetic dyes has opened gigantic benefits to apply solid colours to the textile fibers and fabrics due to their lightweight, ease of processing, quite lower costs and moderate-to-excellent colour fastness properties [1]. However, their discarding process and petroleum-based starting materials have created severe hazardous to our environment due to their non-biodegradable nature [2]. Consequently, many nations have restricted various particular azo-dyes $(-\mathrm{N}=\mathrm{N}-)$ for their applications and manufacturing [3]. In that regard, the replacement of conventional synthetic dyes with natural dyes is an attractive option to mitigate the problems of pollution and hazardous waste [4].
Natural dyes hold great promise of sustainability, offering the potential of being renewable, biodegradable and anti-allergic from harmful additives [5-6]. Moreover, they have a massive worth in the perspective of deteriorating conventional synthetic polymers and global warming associated with it [7]. Thus minimizing environmental impact, the natural dyes have been used for the colouring of textiles materials since Bronze Age [8]. However, in this modern era, their applications and comprehensive usage have been developed towards the antimicrobial finishing of textiles, UV protective clothing, food colorations, cosmetics, and pharmaceuticals etc. [9]. Moreover, the interest and demand in natural dyes are continuously increasing for the reason that it does not implicate any strong acerbic and alkalis in their uses and fabrications [10]. 
The dyes which are derived from natural sources like plants, minerals, and animals are known to be natural dyes [11]. They are colorants that are attained without applying any chemicals. However, the pure dye content and colour yield in dye plant is very low, relative to synthetic dye [12]. In plants, colouring agents are acquired from, leaves, fruits, flowers, roots and barks [13]. Some of the imperative natural dyes are orange, pomegranate, eucalyptus, Kamala, madder, henna, turmeric etc. [14]. Natural dyes have several technical limitations of colour fastness like colour yield, reproducibility results, difficulties of dying procedure and mixing problems [15]. Moreover, natural dyes have poor fastness properties since they have a very low affinity for fibers and fabrics [16]. Therefore mordants are applied with natural dyes to make their affinity with textile fibers during the production [17].

Mordants play a very important role in giving colour to the textile fabric. A mordant is an element which not only causes a chemical reaction but also makes a bridge between the dye and the fabric [18]. It also increases the dye uptake properties between the dye and fibers [19]. It gives different shades when applied in different percentages. Hence it delivers an extensive variability of colour shades with suitable intensities of colour fastness [20]. Sahoo et al. reported the colour shade strength influenced by the concentration of the metal salts used [21]. It also equally depends upon the rise in temperature [22]. The most widely used mordants are ferrous sulphate, copper sulphate, chrome, alum, and stannous chloride etc. [23]. The metal ions of mordants form co-ordinate and covalent bond with the dye molecule. The metal ions accept an electron from the dye molecule which is insoluble in water and thus easily drained out [24]. Subsequently, the size of the dye molecules increased and the light fastness properties improved.

Lyocell is a regenerated cellulosic fiber. It is prepared from wood pulp and is an excellent ecological fabric that specifies a milestone in the progress of environmental sustainable textile [25]. Orange is one of the most common and famous fruit in the world which yearly yield over 100 million tons [26]. Moreover, orange peel (OP) i.e. shell of the orange fruit is the bio-resource wastage and is present in abundance [27]. The bright orange colour extracted from OP generally originates from phenolic compounds [28]. Additionally, it has antimicrobial and UV-protection properties and for that reason could be used as a natural dye or textile finishes [29]. In the literature, many research studies have been done with the dye extracted from orange peel for dyeing textile materials, such as wool and cotton etc. [30-32]. Edeen reported the higher performance mechanical properties of cotton fabric while treated with orange peel extract [31]. Similarly, Kumar and Karan also proved higher performance characteristics of cotton fabric with orange peel and lemon peel extract [33]. Xiuliang $\mathrm{Hou}$ et al. achieved remarkable colour fastness and UV-protection properties in the wool fabric samples dyed with orange peel extract [34]. Formerly no investigation has been described on dyeing Tencel fabric with natural dye extracted from orange peel. Therefore the authors have examined the dyeing and colour fastness of natural dye from orange peel on Lyocell fabric.

In the present study, the chemical composition of OP waste has been determined through physiochemical analysis for pectinase production. The analysed OP waste contained moisture $(40.7 \%)$, ash $(7.39 \%)$, fat $(1.85 \%)$, pectin $(7.0 \%)$, lignin $(6.4 \%)$, crude fiber $(7.8 \%)$, total sugar $(14.08 \%)$, reducing sugars $(10.70 \%)$ and non-reducing sugar $(3.70 \%)$. The Lyocell fabric is dyed with natural dyes extracted from orange peel. Moreover, two mordants (ferrous sulphate and copper sulphate) have also been applied to evaluate the excellence of their application with the Lyocell fabric.

\section{MATERIALS AND METHODS}

\section{Materials}

Dye plant: Orange fruits (Tangerine) were purchased from the local market of Songjiang in Shanghai, China.

Fabric: 100\% Lyocell fabric was used for dyeing, which was obtained from Hangzhou Xinsheng Printing and Dyeing Company LTD (Xiaoshan Hangzhou).

Chemicals: Laboratory grade metallic salts such as ferrous (II) sulphate, (FeSO4.7H2O manufactured by Sinopharm Chemical Reagent, CO.LTD) and (copper (II) sulphate, CuSO4.5H2O manufactured by Sinopharm Chemical Reagent, CO.LTD) were applied as a chemical mordant.

Raw material preparation: Peels were removed from the oranges and washed with water for the removal of the dust particles or other impurities. The washed peels were dried in the oven for 20 hours at a temperature of $30^{\circ} \mathrm{C}$. Subsequently, the dried peels were ground into powder form (for the extraction process) through the grinder machine. Figure 1 has delineated the preparation of raw material.

Equipment: Weighing balance (having accuracy of $0.01 \mathrm{~g}$ ), Water bath, Soxhlet extractor, Water Shaker, Hot air oven, Data colour.

\section{Methods}

Extraction of natural dyes: Aqueous extraction method (Soxhlet apparatus) [6] was used for the extraction of dye from orange peels (OP). $10 \mathrm{~g}$ powder of OP was taken in the round bottom flask with the addition of $200 \mathrm{ml}$ distilled water. Moreover 1:20 material to liquor ratio (M.L.R) was retained. The flask was heated at $90^{\circ} \mathrm{C}$ temperature for 1 hour in the water bath. The vapours passed through the channel and rose up over the top into the condenser. In the thimble, the condensed vapours dropped and thus the extracted material transferred back into the flask and started mixing with the solvent. The thimble was exhausted and continued working for $100 \mathrm{~min}$. After the dye extraction, the solution was filtered 


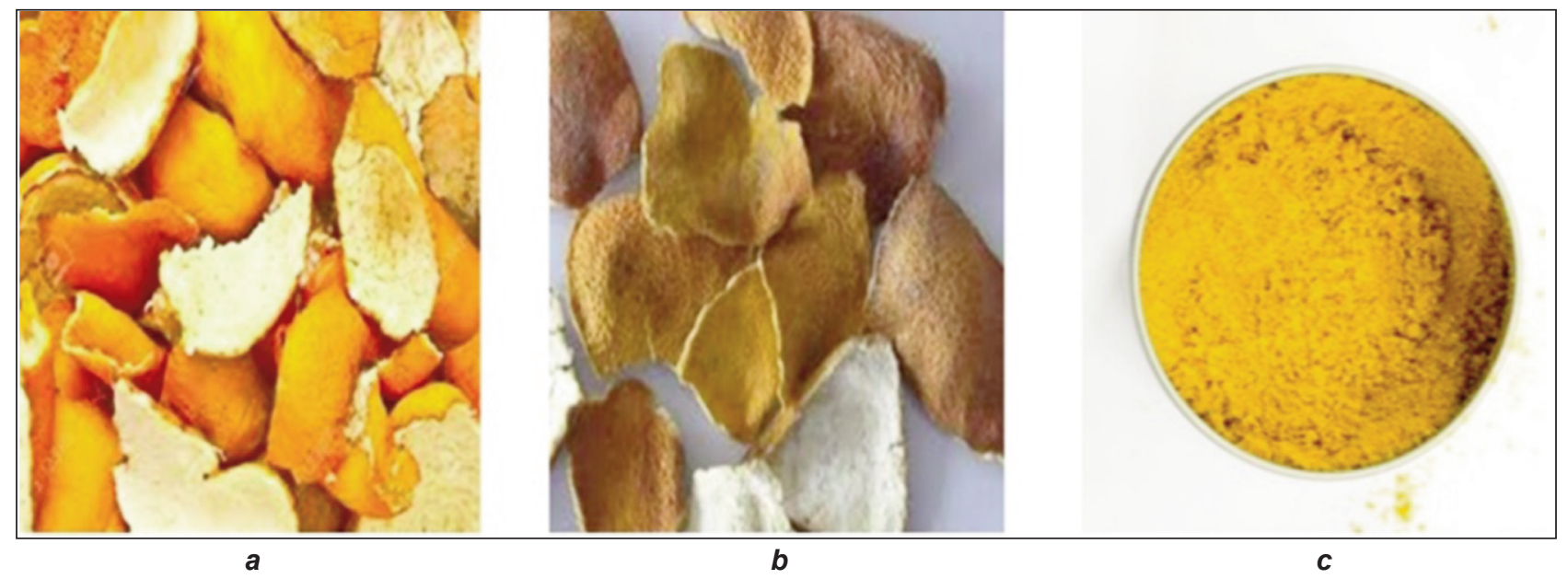

Fig. 1. Preparation of orange peel raw material: $a$ - washed orange peel; $b$-dried orange peel; $c$ - orange peel powder

through Whatman filter paper. It was further purified through a rotary evaporator and was used for the dyeing process.

Mordanting: Lyocell fabric samples were treated separately with two mordants, ferrous sulphate and copper sulphate, for 1 hour at temperature $80^{\circ} \mathrm{C}$. Premordanting technique was applied with liquor ratio $1: 20$. After finishing the mordanting, the Lyocell fabric samples were washed and dried at $26^{\circ} \mathrm{C}$ temperature and further used for the dyeing process.

Dyeing: Lyocell fabric samples were dyed through the exhaust method (Jigger Dyeing machine). The samples were also dyed at different concentrations ( $2 \%$ and $4 \%$ ) in order to compare the effectiveness of the colour results of the fabric samples. The mordants were applied prior to the solution to increasing the dyeability of the Lyocell fabric samples since textile materials have a poor affinity for the dyes. The fabric samples were immersed in the dye solution and dyed for 1 hour with material to liquor ratio (M.L.R; 1:40). The temperature was maintained at $80^{\circ} \mathrm{C}$ for proper diffusion and penetration of dye in the fabric samples. The dye ability of the fabric samples increases with the increase in concentration of the mordants since the dye molecules make strong coordination bonding. Subsequently, the dyed fabric samples were washed with water and soaping agents, and then applied for testing after drying.
Characterization: The dyed fabric samples were examined for different colour fastness properties according to ISO standards like colour fastness to light (ISO 105-B02), washing (ISO 105-C01), rubbing (dry and wet) (ISO 105-X12) and perspiration (ISO 105-E04). Furthermore, the K/S value was used to measure the colour shade strength and dye absorption of the dyed sample.

\section{RESULTS AND DISCUSSIONS}

Orange peel was used for dyeing Lyocell fabric with two types of mordants i.e. ferrous sulfate and copper sulfate, at two different concentrations ( $2 \%$ and $4 \%$ ). With the similarly extracted dye, different shade colors were attained by changing mordants. Different fastness properties were assessed. Moreover, the pre-mordanting method was applied as a mordanting process.

\section{Color measurement and dye absorption}

The dye absorption and color shade of dyed fabric samples were evaluated through K/S values. The dye absorption concentration was measured with the data color SF-600. A number of different color ranges were found on Lyocell fabric samples by using $L^{*}, a^{*}$, $b^{*}, C^{*}, h^{*}$. Table 1 has shown the raw material and different shades of dyeing on the Lyocell fabric samples with ferrous sulfate and copper sulfate at two different concentrations ( $2 \%$ and $4 \%$ ).

\begin{tabular}{|c|c|c|c|}
\hline \multicolumn{4}{|c|}{ EFFECT OF TWO MORDANTS ON LYOCELL FABRIC SAMPLES } \\
\hline Mordants & Raw material & $\mathbf{2 \%}$ concentration & $\mathbf{4 \%}$ concentration \\
\hline $\mathrm{FeSO}_{4}$ & & & \\
\hline $\mathrm{CuSO}_{4}$ & & & \\
\hline
\end{tabular}




\begin{tabular}{|c|c|c|c|c|c|c|c|}
\hline \multicolumn{8}{|c|}{ CIE $L^{*}, a^{*}, b^{*}, C^{*}, h^{*}$ AND K/S VALUES OF DYED LYOCELL FABRIC } \\
\hline Mordant & Concentration (\%) & $\mathrm{K} / \mathrm{S}$ & $\mathbf{L}^{*}$ & $a^{*}$ & $\mathbf{b}^{*}$ & $C^{*}$ & $\mathbf{h}^{*}$ \\
\hline \multirow{2}{*}{$\mathrm{FeSO}_{4}$} & 2 & 2.81 & 54.86 & 2.18 & 3.61 & 4.02 & 82.97 \\
\hline & 4 & 4.0 & 44.93 & 0.31 & 1.25 & 1.28 & 75.85 \\
\hline \multirow{2}{*}{$\mathrm{CuSO}_{4}$} & 2 & 2.06 & 80.05 & 4.67 & 25.71 & 26.13 & 79.72 \\
\hline & 4 & 2.93 & 76.05 & 4.33 & 24.94 & 25.31 & 80.15 \\
\hline
\end{tabular}

Table 2 has shown the overall color shade and $L^{*}, a^{*}$, $b^{*}, C^{*}$ and $h^{*}$ values. It has indicated that lower value of $L^{*}$ has darker shades and higher value of $L^{*}$ has lighter shade for Lyocell and likewise negative values of $a^{*}$ and $b^{*}$ denoted green and blue. Furthermore, the highest color value $(\mathrm{K} / \mathrm{S}=4)$ was obtained with ferrous sulfate and lowest color value $(\mathrm{K} / \mathrm{S}=2.06)$ with copper sulfate. The experimental outcomes indicated that the OP dye using ferrous sulfate with concentration $4 \%$ has promising results on Lyocell fabric. Figure 2 shows the K/S values of Lyocell fabric with mordant (ferrous sulfate and copper sulfate) at concentration $2 \%$ and $4 \%$. Figure 2 depicts that the $\mathrm{K} / \mathrm{S}$ values of dyed Lyocell with mordant ferrous sulfate has higher values at both concentrations than copper sulfate. Colored bars in the figure have represented

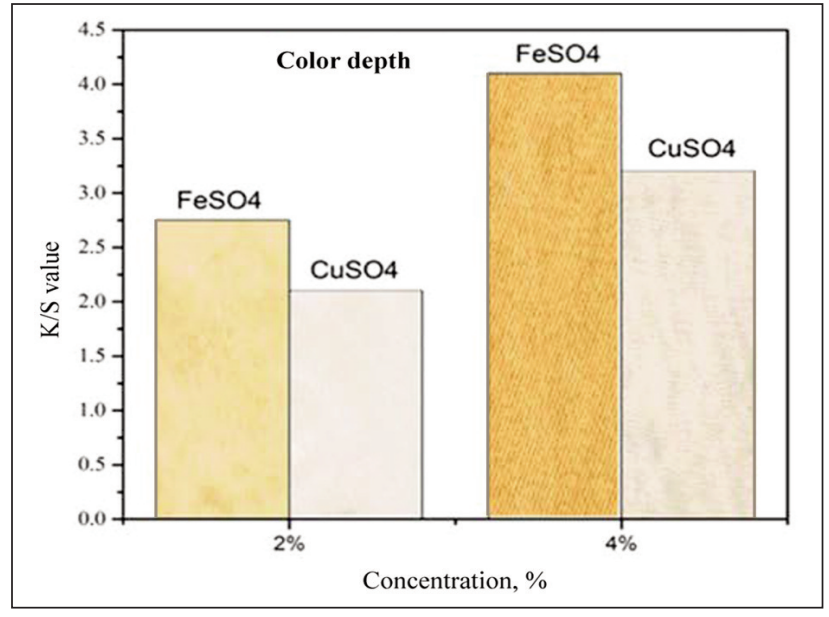

a

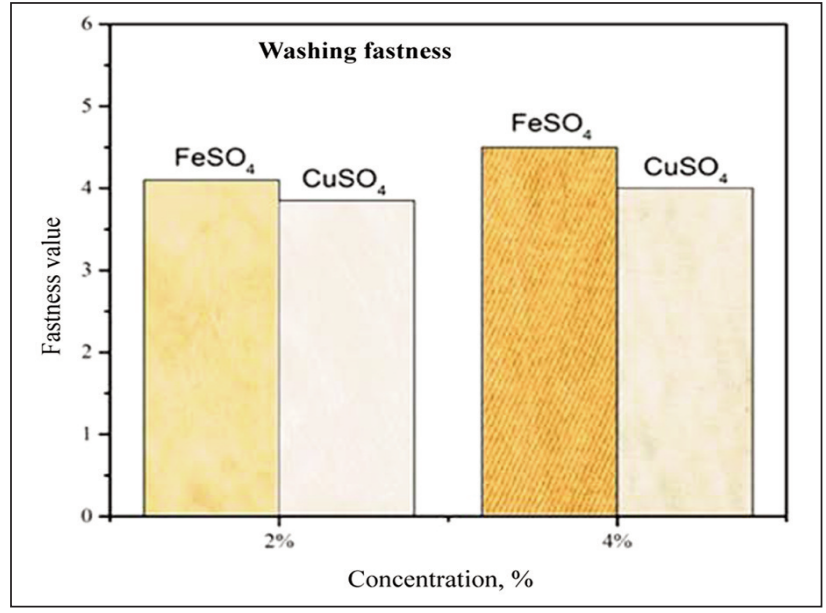

c the outcomes of shade difference at both concentrations with the utilization of both mordants. The highest $\mathrm{K} / \mathrm{S}$ value i.e. 4 was achieved at concentration $4 \%$ with ferrous sulfate and lowest K/S value (2.06) with copper sulfate at concentration $2 \%$.

\section{Color fastness properties of dyed Lyocell}

Extracted dye from orange peel has contributed good washing, light, rubbing and perspiration fastness properties with ferrous sulfate and copper sulfate on Lyocell fabric.

Light fastness: figure 2, a has revealed the result of the lightfastness of Lyocell fabric with orange peel dyed with mordant ferrous sulfate and copper sulfate. It has been observed that ferrous sulfate showed good lightfastness results than the copper sulfate.

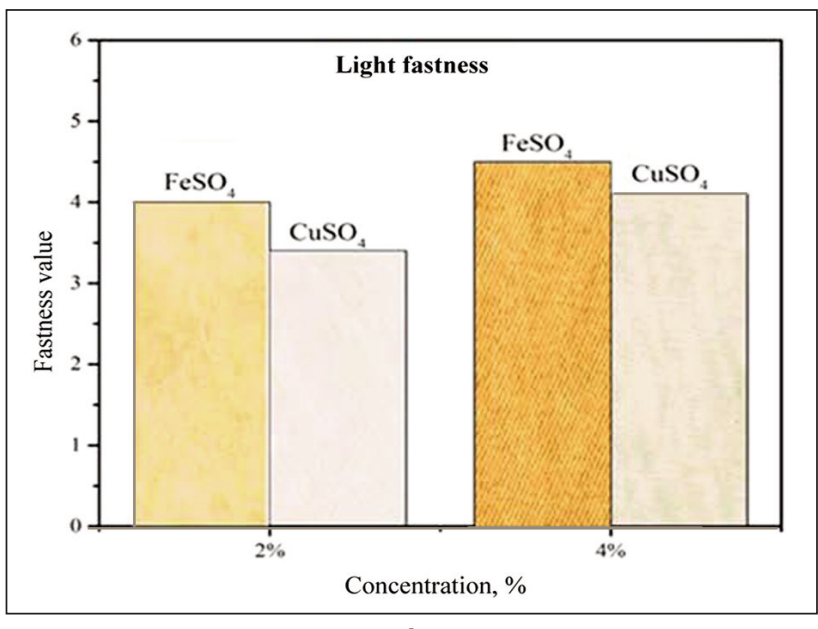

b

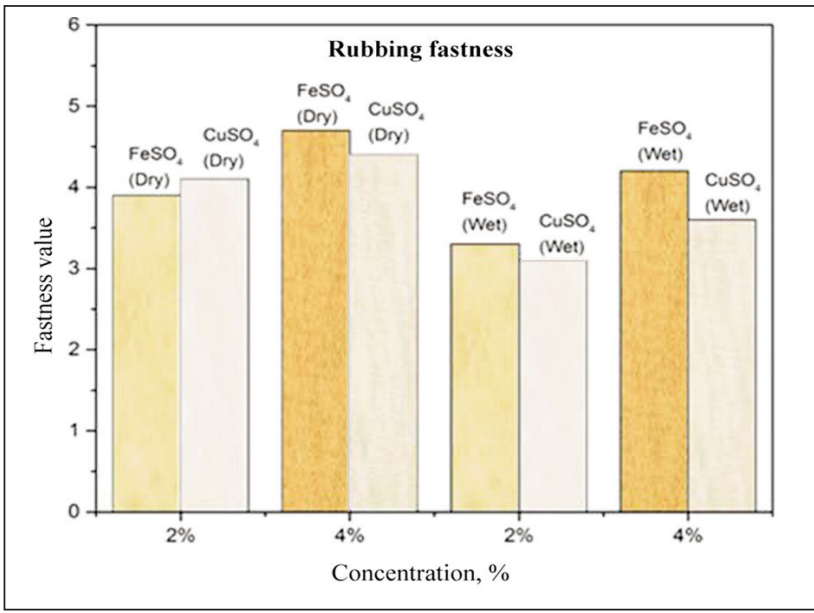

d

Fig. 2. Colour fastness values of dyed Lyocell: $a$ - colour depth; $b$ - light fastness; $c$ - washing fastness; $d$ - rubbing fastness 


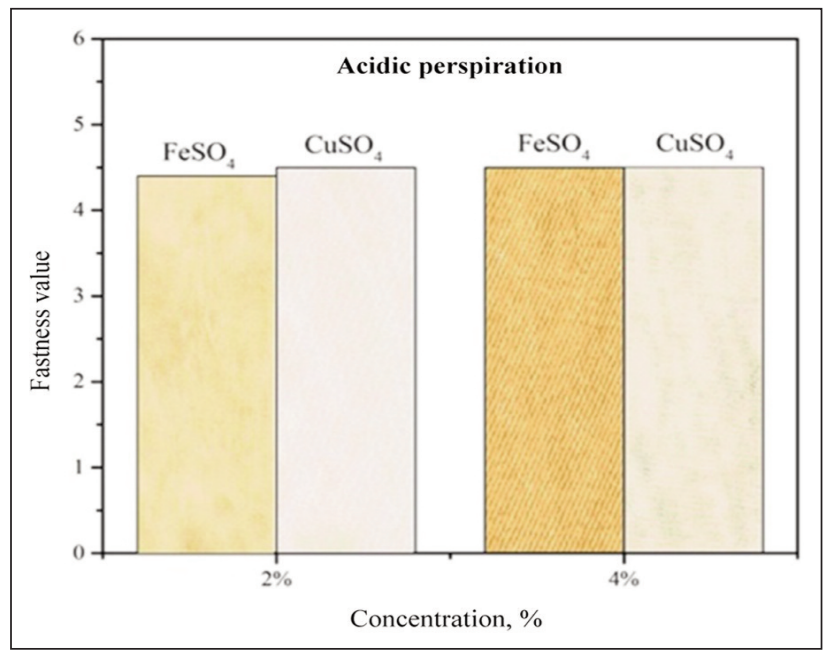

a

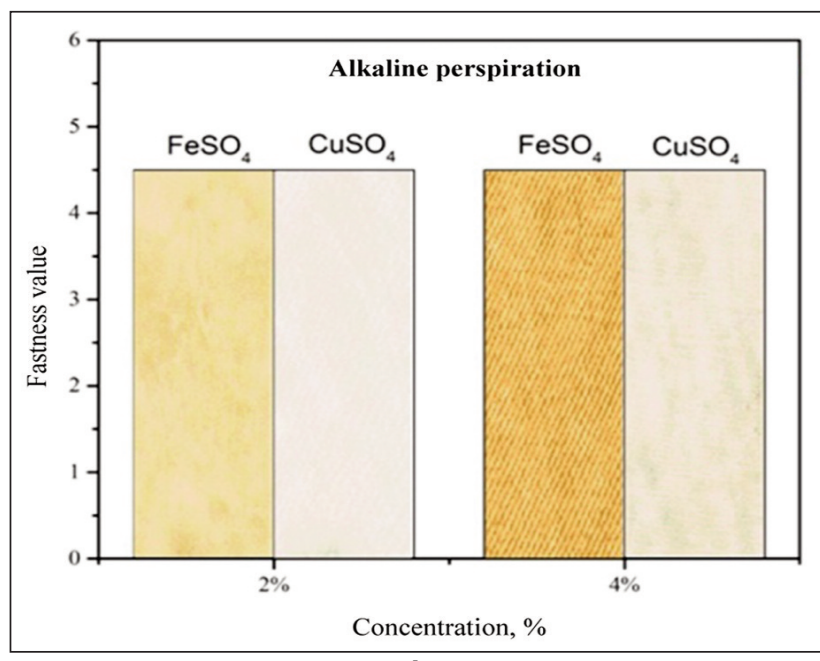

b

Fig. 3. Perspiration fastness result of dyed Lyocell: $a$ - acidic perspiration; $b$ - alkaline perspiration

Through ferrous sulfate, there was no change in color and no color fading. In figure $2, b$ it is evident that dyeing with mordant ferrous sulfate at concentration $4 \%$ has the highest lightfastness (4-5) whereas through copper sulfate light fastness is the lowest (3-5) at concentration $2 \%$. Consequences demonstrated that mordant ferrous sulfate at concentration $4 \%$ is suitable to dye Lyocell fabric.

Washing fastness: figure 2, $c$ has demonstrated the washing fastness effect of dyed Lyocell fabric. The mordant ferrous sulfate has the highest value of washing fastness at both concentrations than copper sulfate. However, at concentration $4 \%$, the results are better (4-5). While with mordant copper sulfate the results are lowest with value (3-4) particularly at concentration $2 \%$. All the samples have a slight change in color (4-5). Figure 2, $c$ also revealed that chemical ferrous sulfate is much better than copper sulfate.

Rubbing fastness (dry and wet): Figure 2, $d$ has presented the rubbing fastness results of Lyocell fabric dyed with extracted dye from orange peel at concentration $2 \%$ and $4 \%$. The light orange and light grey color bars have represented treatment at $2 \%$ while dark orange and dark grey bar colors have displayed the performance at $4 \%$. The mordant ferrous sulfate shows very good to excellent (4-5) dry rubbing and (4) wet rubbing at $4 \%$. Mordant copper sulfate has shown very well (4) dry and wet rubbing fastness at both $2 \%$ and $4 \%$ concentrations. Furthermore, the result depicts that, dry rubbing is better than wet rubbing. Ferrous sulfate showed promising results as compared to copper sulfate at concentration $4 \%$.

Perspiration fastness: Figure $3, a$ and $b$ shows the result of perspiration fastness (acidic and alkali) of Lyocell fabric dyed with orange peel. It was observed that fabric samples treated with ferrous sulfate and copper sulfate exhibit good perspiration fastness at both concentrations i.e. $2 \%$ and $4 \%$. In acidic and alkaline perspiration tests, the fabrics have slight color change (4/5). The staining has also been noticed very light with both chemicals at both concentrations. Table 3 has shown the overall result of colorfastness to washing, light, rubbing (dry and wet) and perspiration fastness of Lyocell fabric dyed with extracted dye from the orange peel with ferrous sulfate and copper sulfate at concentration $2 \%$ and $4 \%$. The performance analysis of colorfastness was also statistically analyzed using t-test (investigate whether the means of two groups or samples are statistically different from each other). Table 4 has shown colorfastness results in $\mathrm{FeSO}_{4}$ and $\mathrm{CuSO}_{4}$ mordants. It was observed a statistically significant difference ( $p$-value $=0.025$ ) in treatments of both mordants at the level of 0.05 . $\mathrm{FeSO}_{4}$ has better results for washing fastness, light fastness, rubbing fastness and perspiration fastness as compared to $\mathrm{CuSO}_{4}$ since ferrous sulfate (green color solution) is a reducing agent and

\begin{tabular}{|c|c|c|c|c|c|c|c|}
\hline \multicolumn{8}{|c|}{ COLOR FASTNESS PROPERTIES OF LYOCELL FABRIC DYED WITH ORANGE PEEL } \\
\hline \multirow{2}{*}{ Mordant } & \multirow{2}{*}{$\begin{array}{c}\text { Concentration } \\
(\%)\end{array}$} & \multirow{2}{*}{$\begin{array}{c}\text { Washing } \\
\text { fastness } \\
\text { ISO 150-C01 }\end{array}$} & \multirow{2}{*}{$\begin{array}{c}\text { Light } \\
\text { fastness } \\
\text { ISO 105-BO2 }\end{array}$} & \multicolumn{2}{|c|}{$\begin{array}{l}\text { Rubbing fastness } \\
\text { ISO 105-X12 }\end{array}$} & \multicolumn{2}{|c|}{$\begin{array}{l}\text { Perspiration fastness } \\
\text { ISO 105-E04 }\end{array}$} \\
\hline & & & & Dry & Wet & Acidic & Alkali \\
\hline \multirow{2}{*}{$\mathrm{FeSO}_{4}$} & 2 & 4 & 4 & 4 & $3-4$ & $4-5$ & $4-5$ \\
\hline & 4 & $4-5$ & $4-5$ & $4-5$ & 4 & $4-5$ & $4-5$ \\
\hline \multirow{2}{*}{$\mathrm{CuSO}_{4}$} & 2 & $3-4$ & $3-4$ & 4 & 3 & $4-5$ & $4-5$ \\
\hline & 4 & 4 & 4 & 4 & $3-4$ & $4-5$ & $4-5$ \\
\hline
\end{tabular}


STATISTICAL T-TEST FOR COLORFASTNESS

\begin{tabular}{|c|c|c|c|c|c|c|}
\hline Mordant & N & Mean & St Dev & $\begin{array}{c}\text { SE } \\
\text { Mean }\end{array}$ & $\begin{array}{c}\text { T- } \\
\text { Value }\end{array}$ & $\begin{array}{c}\text { P- } \\
\text { Value }\end{array}$ \\
\hline $\mathrm{FeSO}_{4}$ & 6 & 4.417 & 0.204 & 0.083 & \multirow{2}{*}{3.16} & 0.025 \\
\hline $\mathrm{CuSO}_{4}$ & 6 & 4.083 & 0.376 & 0.154 & & \\
\hline
\end{tabular}

has lower solubility while copper sulfate (blue color solution) is a weak oxidizing agent and has higher solubility.

\section{CONCLUSIONS}

In the present study, Lyocell fabric was dyed with orange peel. The aqueous extraction method was used to extract dye from orange peel. Two mordants, ferrous sulphate, and copper sulphate were used to analyse the colour strength and washing, light and rubbing fastness properties of Lyocell fabric. The pre-mordanting method was used with $2 \%$ and $4 \%$ concentrations to evaluate the effect of colour shades. Both mordants showed good results on Lyocell fabric. However ferrous sulphate was better than copper sulphate. The overall result revealed that ferrous sulphate is a better choice for Lyocell fabric dyeing at concentration $4 \%$ since it has a good colour efficiency (K/S: 4) and colour fastness to washing (4-5), light (5), rubbing (4-5) and perspiration (4-5). The performance analysis of colour fastness was also statistically significant at the 0.05 level. Also, the Lyocell fabric dyed with natural citrus aurantium can be a breakthrough to environmental safety and human health fortification.

\section{ACKNOWLEDGEMENT}

The research was supported by the Fundamental Research Funds for the Central Universities (No.17D310503) and National Natural Science Foundation of China (No.51403032).

\section{REFERENCES}

[1] Rehman, F., Sanbhal, N., Naveed, T., Farooq, A., Wang, Y., Wei, W., Antibacterial performance of Tencel fabric dyed with pomegranate peel extracted via ultrasonic method, In: Cellulose Journal, 2018, 25, 4251-4260

[2] Adeel, S., Ali, S, Bhatti, I.A., Zsila, F., Dyeing of cotton fabric using pomegranate (Punica granatum) aqueous extract, In: Asian Journal of Chemistry, 2009, 21, 5, 3493-3499

[3] Patel, N., Natural dye based sindoor, In: Life Sciences Leaflets, 2011, 11, 355-361

[4] Kulkarni, S., Bodake, U., Pathade, G., Extraction of Natural Dye from Chili (Capsicum Annum) for Textile Coloration, In: Universal Journal of Environmental Research \& Technology, 2011, 1, 1, 58-63

[5] Shahid, M., Mohammad., F, Perspectives for natural product based agents derived from industrial plants in textile applications - a review, In: Journal of cleaner production, 2013,57, 2-18

[6] Rehman, F., Naveed, T., Yousafzai, W., Wei, W., Study on Tencel Fabric Dyeing with Pomegranate Peel Natural Dyes, In: Asian Journal of Chemistry, 2017, 29, 10, 2279-2284

[7] Jung, J.S., Natural Dyeing of Cotton and Silk with Red Pigment Extract from Safflower, In: International Journal of u-and e-Service, Science and Technology, 2016, 9, 8, 161-168

[8] Davulcu, A., Benli, H., Sen, Y., Bahtiyari, M.I., Dyeing of cotton with thyme and pomegranate peel, In: Cellulose, $2014,21,6,4671-4680$

[9] Lokesh, P., Swamy, M., Extraction of natural dyes from Spathodea campanulata and its application on silk fabrics and cotton, In: Der ChemicaSinica, 2013, 4, 1, 111-115

[10] Mahanta, D., Tiwari, S., Natural dye-yielding plants and indigenous knowledge on dye preparation in Arunachal Pradesh, northeast India, In: Current science, 2005, 1474-1480

[11] Sachan, K., Kapoor., V., Optimization of extraction and dyeing conditions for traditional turmeric dye, In: Indian Journal of traditional knowledge, 2007, 6, 2, 270-278

[12] Siva, R., Status of natural dyes and dye-yielding plants in India, In: Current Science, 2007, 92, 7

[13] Farooq, A., Ali, S., Abbas, N., Zahoor, N., Ashraf, M.A., Optimization of extraction and dyeing parameters for natural dyeing of cotton fabric using Marigold (Tagetes erecta), In: Asian Journal of Chemistry, 2013, 25, 11, 5955-5959

[14] Pruthi, N., Chawla, G.D., Yadav, S., Dyeing of silk with barberry bark dye using mordant combination, In: Natural Product Radiance, 2008, 7, 1, 40-44

[15] Win, Z.M., Swe, M.M., Purification of the natural dyestuff extracted from Mango bark for the application on protein fibers, In: World Acad Sci Eng Technol, 2008, 22, 536-540

[16] Samanta, A.K., Agarwal, P., Application of natural dyes on textiles, In: Indian Journal of Fiber \& Textile Research, 2009, 34, 4, 384-399

[17] Vankar, P.S., Dyeing Cotton, Silk and Wool yarn with extract of Garcinia mangostana pericarp, In: Journal of Textile and Apparel, Technology and Management, 2009, 6, 1, 326-335

[18] Ali, S., Nisar, N., Hussain, T., Dyeing properties of natural dyes extracted from eucalyptus, In: Journal of the Textile Institute, 2007, 98, 6, 559-562

[19] Wanyama, P.A.G., Kiremire, B.T., Ogwok, P., Murumu, J.S., The effect of different mordants on strength and stability of color produced from selected dye-yielding plants in Uganda, In: International Archive of Applied Sciences and Technology 2015, 1, 2, 81-92

[20] Kamel, M., Helmy, H., Hawary, N.E.I., Some studies on dyeing properties of cotton fabrics with crocus sativus (Saffron flowers) using an ultrasonic method, In: Journal of Natural Fibers, 2009, 6, 2,151-170 
[21] Sahoo, T., Bhattacharya, G., Dash, S.K., Effectiveness of Different Mordants and Concentrations on the Dyeing Properties of Jackfruit (Atrocarpus heterophyllus) Bark on Silk, In: International Journal of Agriculture, Environment and Biotechnology, 2017, 10, 5, 565-573

[22] Mongkholrattanasit, R., et al., Dyeing, fastness, and UV protection properties of silk and wool fabrics dyed with eucalyptus leaf extract by the exhaustion process, In: Fibers \& Textiles in Eastern Europe, 2011, 19, 94-99

[23] Borbély, É., Lyocell, the new generation of regenerated cellulose, In: Acta Polytechnica Hungarica, 2008, 5, 3, 11-18

[24] Sawalha, S.M., Arraez Roman, D., Segura Carretero, A., Fernandez Gutierrez, A., Quantification of main phenolic compounds in sweet and bitter orange peel using CE-MS/MS, In: Food Chemistry, 2009, 116, 2, 567-574

[25] Curl, A., Bailey, G., Orange Carotenoids, Part I-Comparison of Carotenoids of Valencia Orange Peel and Pulp, Part II-Carotenoids Aged Canned Valencia Orange Juice, In: Journal of Agricultural and Food Chemistry, 1956, 4, 2 , 156-162

[26] Oreopoulou, V., Tzia, C., Utilization of plant by-products for the recovery of proteins, dietary fibers, antioxidants, and colorants, In: Utilization of by-products and treatment of waste in the food industry, Springer, 2007, 209-232

[27] Moussaid, M., Caillet, S., Nketsia Tabiri, J., Boubekri, C., Lacroix, M., Phenolic compounds and the colour of oranges subjected to a combination treatment of waxing and irradiation, In: Journal of the Science of Food and Agriculture, 2004, 84, 13, 1625-1631

[28] Hou, X., Chen, X., Cheng, Y., Xu, H., Chen, L., Yang, Y., Dyeing and UV-protection properties of water extracts from orange peel, In: Journal of cleaner production, 2013, 52, 410-419

[29] Kumar, C., Dhinakaran, M., Extraction and application of natural dyes from orange peel and lemon on cotton fabrics, In: Textile Research Journal, 2017, 80, 2117-2123

[30] Edeen, A.B., Dyeing of Egyptian Cotton Fabrics with Orange Peel Using Padding Technique, In: International Design Journal, 2015, 5, 3, 733-744

[31] Ahmed, I., Zia, M.A., Hussain, M.A., Akram, Z., Naveed, M.T., Nowrouzi, A., Bioprocessing of citrus waste peel for induced pectinase production by Aspergillus niger; its purification and characterization, In: Journal of Radiation Research and Applied Sciences, 2016, 9, 2, 148-154

[32] Maha-In, K., Mongkholrattanasit, R., Klaichoi, C., Pimklang, W., Buathong, P., Rungruangkitkrai, N., Dyeing Silk Fabric with Natural Dye from Longan Leaves Using Simultaneous Mordanting Method, In: Materials Science Forumm, 2016, 857, 491-494

[33] Sentthil Kumar, C.S., Dhinakaran, M., Extraction and Aapplication of Natural Dyes From Orange Peel and Lemon Peel on Cotton Fabrics, In: International Research Journal of Engineering and Technology, 2017, 4, 5, 237-244

[34] Hou, X., Chen, X., Cheng, Y., Xu, H., Chen, L., Yang, Y., Dyeing and UV-Protection Properties of Water Extracts from Orange Peel, In: Journal of Cleaner Production, 2013, 52, 410-419

Authors:

NAVEED TAYYAB ${ }^{1,2,3}$, RASHDI YASEEN SAYED ${ }^{1}$, REHMAN FAISAL $^{1}$, WEI WANG ${ }^{1,4}$, AWAN ASHRAF JAVEED ${ }^{3}$, ABBAS MUDASSAR ${ }^{3}$, FRAZ AHMAD ${ }^{3}$, AWAIS MUHAMMAD $^{2,5}$

${ }^{1}$ College of Chemistry, Chemical Engineering and Biotechnology, Donghua University, 201620, Shanghai, China

email: 414006@mail.dhu.edu.cn, sayedyaseenrashdi@outlook.com, faisal.dhu@qq.com

${ }^{2}$ School of Textile and Design, University of Management and Technology, Johar Town, 54770, Lahore, Pakistan

${ }^{3}$ Department of Textile Engineering \& Technology, University of the Punjab, 54590, Lahore, Pakistan

email: chairman.tet@pu.edu.pk; mudassar.abbas@umt.edu.pk, ahmad.fraz@umt.edu.pk

${ }^{4}$ Saintyear Holding Group Co., Ltd., Xiaoshan, Hangzhou, 311221, Zhejiang, China

${ }^{5}$ Institute of Textile Machinery and High Performance Material Technology,

TU Dresden, 01062 Dresden, Germany

email: muhammad.awais1@tu-dresden.de

Corresponding author:

WEI WANG

e-mail:wangv@dhu.edu.cn 